personell med kompetanse $\mathrm{i}$ å sikre luftveier. I vårt tilfelle var det kort reisevei til nærmeste øre-nese-hals-avdeling, under ti minutter, og det å tilkalle anestesikyndig personale til legevakten ble vurdert å skape unødvendige forsinkelser.

Avhengig av pasientens respiratoriske besvær må anestesikyndig lege, om mulig i samråd med øre-nese-hals-lege, vurdere riktig metode for sikring av luftveier. Ved en truende luftveissituasjon forsøkes i første omgang konvensjonell intubering eller intubering via fleksibelt skop. Dersom situasjonen er svært kritisk og intubasjon ikke kan gjenomføres grunnet trange forhold, utføres nødtrakeotomi/koniotomi. En enkel og forholdvis sikker måte å gjøre koniotomi på er å bruke et ferdigmontert koniotomisett. Hvis man har god tid, kan konvensjonell trakeotomi i lokalbedøvelse være et alternativ. Enkelte erfarne halskirurger har i den akutte, kritiske situasjonen gått direkte for en konvensjonell trakeotomi, men dette kan ikke anbefales generelt, grunnet risiko for store blødninger.

Denne kasuistikken illustrerer at epiglottitt ikke er en utryddet sykdom. Det er viktig ikke å glemme denne differensialdiagnosen, da tilstanden kan utvikle seg svært raskt og bli livstruende. Kasuistikken viser hvor viktig det er å være årvåken, gjøre grundige undersøkelser og eventuelt rådføre seg med mer erfarne kolleger når pasientens plager ikke stemmer overens med vanlige tilstander.

Pasienten har gitt samtykke til at artikkelen blir publisert.

\section{Rebecca Bhatti (f. 1978)}

har jobbet ved Allmennlegevakten ved Legevakten i Oslo siden 2009. Hun har vært halvannet år som lege i spesialisering ved medisinsk avdeling ved Levanger sykehus.

Forfatter har fylt ut ICMJE-skjemaet og oppgir ingen interessekonflikter.

\section{Tone Solvik-Olsen (f. 1976)}

er lege i spesialisering ved barnemedisinsk avdeling ved Sykehuset Telemark. Hun har tidligere jobbet tre år ved Allmennlegevakten ved Legevakten i Oslo.

Forfatter har fylt ut ICMJE-skjemaet og oppgir ingen interessekonflikter.

\section{Karl Fredrik Nordfalk (f. 1976)}

er spesialist i øre-nese-hals-sykdommer og overlege ved Øre-nese-hals-avdelingen, Oslo universitetssykehus, Rikshospitalet. Han er opptatt i ph.d.-programmet ved Universitetet i Oslo og forsker på skader i balansesystemet etter cochleaimplantasjon.

Forfatter har fylt ut ICMJE-skjemaet og oppgir ingen interessekonflikter.

\section{Odd Martin Vallersnes (f. 1969)}

er spesialist i allmennmedisin og legeskiftleder ved Allmennlegevakten ved Legevakten i Oslo. Han er stipendiat ved Avdeling for allmennmedisin ved Universitetet i Oslo og forsker på behandling av akutte rusmiddelforgiftninger på legevaktnivå.

Forfatter har fylt ut ICMJE-skjemaet og oppgir ingen interessekonflikter.
Litteratur

1. Melbye H, Hjortdahl P, Langhammer A. Lunger og luftveier. I: Hunskår S, red. Allmennmedisin. 2. utg. Oslo: Gyldendal Akademisk, 2003: 135.

2. Norsk helseinformatikk. Difteri. http://nhi.no/ livsstil-og-helse/reisemedisin/sykdommer/ difteri-1740.html (7.2. 2012)

3. Folkehelseinstituttet. Barnevaksinasjonsprogram met. http://www.fhi.no/eway/default.aspx?pid= 233\&trg=Main Left 5631\&MainArea 5661 $=5631 \cdot 0$ 15,4537:1:0:0:0:0\&MainLeft_5631=5544:69485:1 5641:1:0:0 (7.2. 2012)

4. Mayo-Smith MF, Spinale JW, Donskey CJ et al. Acute epiglottitis. An 18-year experience in Rhode Island. Chest 1995; 108: 1640-7.

5. Bizaki AJ, Numminen J, Vasama JP et al. Acute supraglottitis in adults in Finland: review and analysis of 308 cases. Laryngoscope 2011: 121: 2107-13.

. Isakson M, Hugosson S. Acute epiglottitis: epidemiology and Streptococcus pneumoniae serotype distribution in adults. J Laryngol Otol 2011 125: $390-3$

7. Frantz TD, Rasgon BM, Quesenberry CP Jr. Acute epiglottitis in adults. Analysis of 129 cases. JAMA 1994: 272: 1358-60.

8. Briem B, Thorvardsson O, Petersen H. Acute epiglottitis in Iceland 1983-2005. Auris Nasus Larynx 2009: 36: 46-52.

9. McEwan J, Giridharan W, Clarke RW et al. Paediatric acute epiglottitis: not a disappearing entity Int J Pediatr Otorhinolaryngol 2003; 67: 317-21.

10. Price IM, Preyra I, Fernandes CM et al. Adult epiglottitis: a five-year retrospective chart review in a major urban centre. CJEM 2005; 7: 387-90.

11. Al-Qudah M, Shetty S, Alomari M et al. Acute adult supraglottitis: current management and treatment. South Med J 2010; 103: 800-4.

12. Katori H, Tsukuda M. Acute epiglottitis: analysis of factors associated with airway intervention. J Laryngol Otol 2005; 119: 967-72.

13. $\mathrm{Ng} \mathrm{HL}$, Sin LM, Li MF et al. Acute epiglottitis in adults: a retrospective review of 106 patients in Hong Kong. Emerg Med J 2008; 25: 253-5.

14. Park KW, Darvish A, Lowenstein E. Airway management for adult patients with acute epiglottitis: a 12-year experience at an academic medical center (1984-1995). Anesthesiology 1998; 88: 254-61.

\title{
Et forbilledlig behandlingsløp - fordi det skjedde i Oslo sentrum?
}

Epiglotitt er en sjelden sykdom. Hos voksne er sår hals og svelgevansker de vanligste symptomene. Bhatti og medarbeidere beskriver en tidligere frisk mann i 30-årene som under to timer etter at han oppsøkte legevakten ble overflyttet til universitetssykehus i ambulanse. Ved ankomst til akuttmottaket var han bevisstløs og ble nødtrakeotomert. Åtte dager senere ble han utskrevet.

I artikkelen beskrives et forbilledlig behandlingsforløp - som uten tvil berget pasientens liv. Det vil særlig være legevakttjenesten og fagområdene øre-nese-hals og anestesi som kan lære noe av denne kasuistikken. Kommentarene herunder vil knytte seg at hendelsen skjedde $i$ en by med universitetssykehus, ikke i deler av landet med andre geografiske forhold og helt andre for- utsetninger når det gjelder medisinsk kompetanse i tilstedevakt.

I tillegg til beslutningen om å overflytte pasienten til sykehus i tide var det særlig tre kritisk viktige faktorer som var helt avgjørende for utfallet i denne kasuistikken.

Transporttid. Blodgass ved ankomst sykehuset viste $\mathrm{pH}$ 6,6 (7,35-7,43). Det er derfor innlysende at pasienten overlevde fordi transporttiden fra legevakten til nærmeste ørenese-hals-avdeling var svært kort (under ti minutter).

Kompetanse. Tilstedeværelse av øre-nesehals-spesialist ved sykehuset den aktuelle natten var avgjørende for at pasienten fikk adekvat behandling. Selv ved universitetssykehusene vil det ikke alltid være øre-nesehals-spesialist som har tilstedevakt. Ved mel- lomstore sykehus med øre-nese-hals-avdeling vil det oftest være lege i spesialisering som har tilstedevakt, og her vil det som regel også være lege i spesialisering som har tilstedevakt $\mathrm{i}$ anestesiavdelingen. Ved sykehus uten øre-nese-hals-lege som tilstedevakt må man anta at anestesilegen vil spille en vesentlig rolle $\mathrm{i}$ håndteringen av tilfeller av «vanskelig luftvei». Ved disse sykehusene vil dette som regel være spesialist $\mathrm{i}$ anestesi. Disse har ofte ikke tilstedevakt.

Nødtrakeotomi. Etter mislykket intubasjonsforsøk av anestesilege og øre-nese-halsspesialist valgte sistnevnte å nødtrakeotomere. Dette berget pasientens liv. Omfanget av nødtrakeotomi i Norge er ukjent, men mest sannsynlig er det lavt. Trakeotomi har tradisjonelt vært øre-nese-hals-fagets domene, 


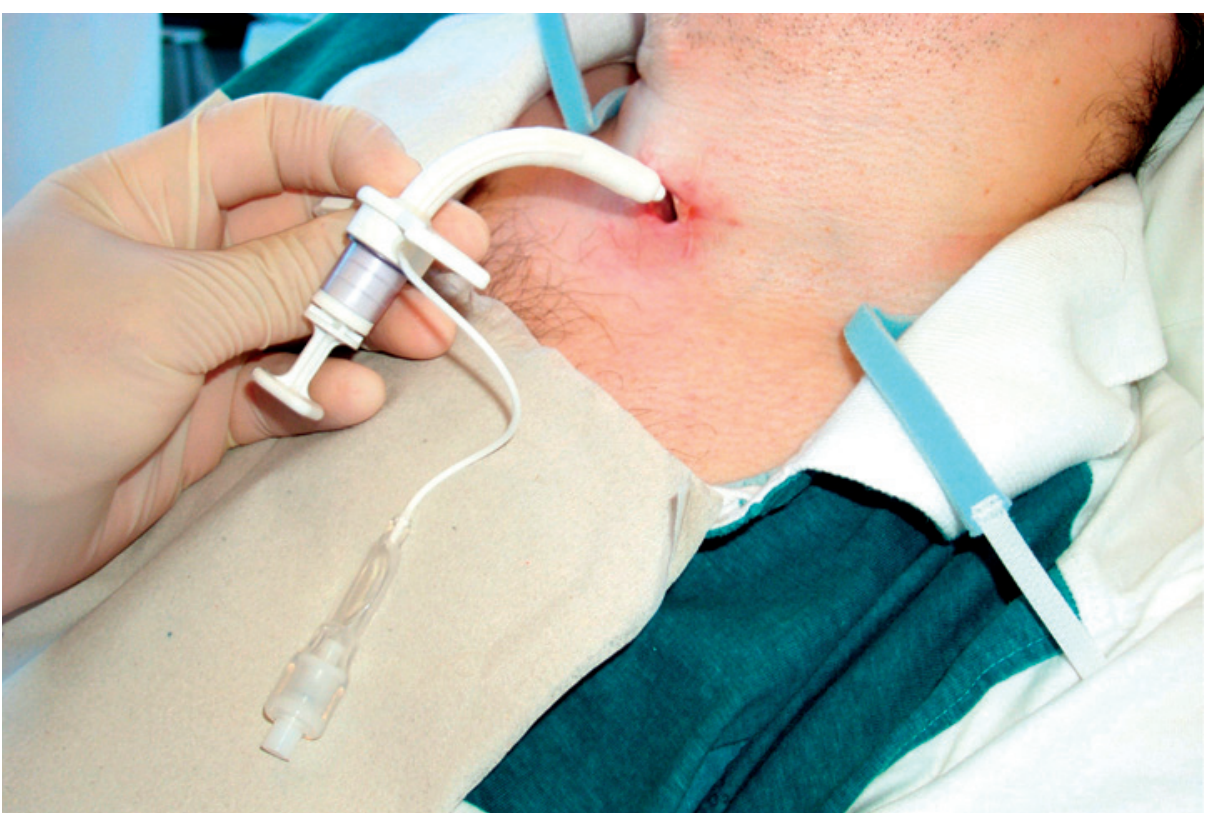

Nødtrakeotomi kan være et livbergende tiltak ved epiglotitt - her innleggelse av trakeostomitube via etablert trakeostoma. Pasienten har gitt samtykke til at bildet blir publisert. Foto K. Dybwik

men flere faktorer har endret dette. Ny teknologi, blant annet bruk av direkte videolaryngoskopi, har revolusjonert anestesilegens muligheter til å etablere kunstig luftvei i vanskelige luftveier. Utviklingen av slik teknologi og kompetanse i å bruke den vil mest sannsynlig føre til at tallet på nødtrakeotomier vil gå ned.

Elektiv trakeotomi danner et viktig erfaringsgrunnlag for utførelsen av nødtrakeo- legene og anestesilegene får tilstrekkelig øvelse i å utføre nødtrakeotomi i en stressende akuttsituasjon?

Et viktig rettferdighetsprinsipp i et offentlig helsevesen er at like tilfeller skal behandles likt. Denne kasuistikken viser at geografiske forhold og ulik fordeling av spisskompetanse kan være forskjellen på liv og død.

\section{Knut Dybwik \\ kdybwik@gmail.com \\ Intensivavdelingen \\ Nordlandssykehuset Bodø}

Knut Dybwik (f. 1961) er intensivsykepleier/ dr.philos. Han arbeider ved Intensivavdelingen ved Nordlandssykehuset Bodø. Hans spesialområde er respiratorbehandling og trakeostomi i og utenfor sykehus.

Forfatter har fylt ut ICMJE-skjemaet og oppgir ingen interessekonflikter.

\section{Litteratur}

1. Sollid SJ, Strand K, Søreide E. Percutanous dilatational tracheotomy in the ICU: a Norwegian survey focusing on perceived risk and safety attitudes. Eur J Anaesthesiol 2008; 25: 925-32.

2. Bjerkelund $C E$, Christensen $P$, Dragsund $S$ et al. Hvordan oppnå fri luftvei? Tidsskr Nor Legeforen 2010: 130: 507-10. tomi er den foretrukne metoden ved de fleste norske sykehus (1), og det er i all hovedsak anestesilegene $\mathrm{i}$ intensivavdelingene som gjør dette. Sannsynligvis utgjør dette over halvparten av alle trakeotomier som utføres i Norge (2). Spørsmålet er om øre-nese-hals-
Mottatt 20.3. 2012, første revisjon innsendt 25.3. 2012, godkjent 29.3. 2012. Medisinsk redaktør Trine B. Haugen. 